HELMINTHOLOGIA, 52, 3: 252 - 260, 2015

\title{
Effect of heavy metals on soil nematode communities in the vicinity of a metallurgical plant in North Slovakia
}

\author{
P. ŠALAMÚN, V. HANZELOVÁ, D. MIKLISOVÁ, T. BRÁZOVÁ \\ Institute of Parasitology, SAS, Hlinkova 3, 04001 Košice, Slovak Republic \\ E-mail: salamun@saske.sk
}

\section{Article info}

Received November 11, 2014 Accepted March 19, 2015

\begin{abstract}
Summary
The effect of industrial pollution from chromium ferroalloys production on soil free-living nematode assemblages, c-p groups and generic composition was investigated along 7-km transect. From trace elements $(\mathrm{Cr}, \mathrm{Cu}, \mathrm{Ni}$ and $\mathrm{Pb}$ ), only chromium exceeded the thresholds for uncontaminated soils (10 mg. kg ${ }^{-1}$ ) near the pollution source. In contrast mobilizable fraction of $\mathrm{Cr}$ has increased with the distance from the pollution source and was found to be positively correlated with $\mathrm{C}_{\mathrm{ox}}$, soil $\mathrm{pH}$, and moisture. Generic richness (nematode diversity) was also higher at remote sites. The low contamination has no significant impact on the nematode communities as illustrated by the c-p groups composition and balanced community structure. Widely applied ecological indices SI and El also proved maturing ecosystem without any significant stress responses.
\end{abstract}

Keywords: nematode community; chromium; contamination; metallurgical plant

\section{Introduction}

Soil as an important source of different valuable services is often taken into account as a very fragile part of the ecosystem with a relatively low capability of restoration. Its self-cleaning abilities are limited and heavy loads of contaminants or brusque interventions of agricultural practises could, in some cases, lead to the deterioration and erosion (Park et al., 2011). Unfortunately, soil in these days serves as a main storage sink for different wastes and contaminants (Zhang et al., 2007). One of the major concerns is contamination in the close vicinity of industrial complexes, where dust particles or different volatile compounds are releasing into the atmosphere and usually ends in the soil ecosystem (Li et al., 2006). The most severe impact of these compounds is reflected in soil biota and their population dynamics and could lead to disruption in important positive processes (mineralization, nutrient cycling, etc.) and enhanced the soil erosion (Haimi \& Mätäsniemi, 2002).

The well-known responses of edaphon are good indicators for stress increase and widely applied for biomonitoring (Bongers \& Ferris, 1999). Among wide variety of soil animal groups, nematodes, with easily readable stress reactions, look very promising
(Ferris et al., 2001). In recent history, different ecological indices (MI, PPI, SI, Cl etc.), designed specifically for analysis of nematode assemblages (Neher et al., 2004) facilitate the insight in soil ecosystem perturbations and are able to reveal the complexity of interactions of nematode communities with other ecosystem components. Numerous studies (e.g. Sánchez-Moreno \& Navas, 2007; Pen-Mouratov et al., 2010) described bioindication of different impacts using nematodes with the adequate and easy interpretation. The aim of this study was to find out the extent of soil contamination by heavy metals fallout, in particular $\mathrm{Cr}$, near metallurgical factory as a by-product of ores processing. The solid particles in emissions are formed mainly by mobile $\mathrm{Cr}$ compounds with the addition of other potentially hazardous elements e.g. $\mathrm{Cu}, \mathrm{Ni}, \mathrm{Pb}$ (Fargašová, 2009). Therefore, we assume that the soil ecosystem and the native nematode communities may be negatively altered due to the metals, especially the mobile form of $\mathrm{Cr}$. The questions addressed were: (i) what is the extent of the soil contamination in the study site, (ii) are the mobilizable fractions of particular elements $(\mathrm{Cr}, \mathrm{Cu}, \mathrm{Ni}$ and $\mathrm{Pb})$ in the correlation with the emissions, and if so, (iii) are these changes in soil recognizable in the structure of nematode assemblages? 


\section{Material and Methods}

\section{Site description}

Orava Ferro-alloy Works (Oravské Ferozliatinárske Závody, OFZ a. s.), the former largest central European manufacturer of ferroalloys, is located in the city Istebné located in the central part of the Orava district, North Slovakia (49 $12^{\prime} 42^{\prime \prime} \mathrm{N}$ and $\left.19^{\circ} 13^{\prime} 19^{\prime \prime} \mathrm{E}\right)$. The region is hilly with distinctive continental climate (mean annual temperature is $7^{\circ} \mathrm{C}$; annual precipitation usually $750-860$ $\mathrm{mm}$ ) and prevailing west and north winds. Soils were exceedingly stony Cambisol and Rendzic Leptosol with slight acid $\mathrm{pH}$ and $\mathrm{C}_{\text {ox }}$ between 1.55 and $3.57 \%$. The soil nitrogen fractions $\mathrm{NO}_{3}^{-}$and $\mathrm{NH}_{4}^{+}$range from 4.58 to $7.35 \mathrm{mg} . \mathrm{kg}^{-1}$ and 6.03 to $13.20 \mathrm{mg}^{\mathrm{kg}}{ }^{-1}$, respectively. The soil moisture was around $20 \%$, except site 4 , were $31.42 \%$ of soil moisture was found (Table 1).

The factory itself began production in 1952 and was closed after almost 50 years of continuous production, but released emissions represent the ecological risk till these days. For example, as many as 320.1 tons of solid particles were emitted from the factory during the year 1996 (Kropitz \& Pivarči, 1998). According to Fargašová (2009), the major contaminants are mobile forms of $\mathrm{Cr}$ and to less extent $\mathrm{Cu}, \mathrm{Ni}$ and $\mathrm{Pb}$.
3) $\mathrm{NH}_{4}^{+}$was determined spectrophotometrically using Nessler reagent.

4) $\mathrm{NO}_{3}^{-}$was determined by an ion-selective electrode.

5) $\mathrm{pH}$ was determined in $\mathrm{CaCl}_{2}$ solution (ISO/DIS 10390).

6) The total and mobilizable concentration of trace elements $(\mathrm{Cu}, \mathrm{Cr}, \mathrm{Ni}, \mathrm{Pb}$ was determined by an ICP-MS method using Agilent $7500 \mathrm{C}$. Before the analysis, replicates were airdried, pounded and sifted through the $0.2 \mathrm{~mm}$ sieve. Metals were extracted by $2 \mathrm{M} \mathrm{HNO}_{3}$ (Sabienë et al., 2004) and 0.05M $\mathrm{Na}_{2}$ EDTA for total and mobilizable content, respectively (Sabienë et al., 2004).

Steps $1-4$ were performed by Laboratory of the Central and Testing Institute in Agriculture in Košice, according to the certified methods (MARD, 2005).

\section{Nematode community analysis}

Nematode community was determined by extraction from $100 \mathrm{~g}$ of soil samples from each replicate using modified Baermann funnel method (Southey, 1986). The extracted nematodes were fixed in Ditlevsen's solution (van Bezooijen, 2006), counted and identified to the generic level using a compound microscope NICON. For nematode communities analysis, following parameters were

Table 1. Sampling site description

\begin{tabular}{|c|c|c|c|c|c|}
\hline Site characteristics & $\begin{array}{c}\text { Emission source } \\
\text { (ES) }\end{array}$ & 1 & 2 & 3 & 4 \\
\hline GPS position & $\begin{array}{l}49^{\circ} 12^{\prime} 00^{\prime \prime} \mathrm{N} \\
19^{\circ} 13^{\prime} 36^{\prime \prime} \mathrm{E}\end{array}$ & $\begin{array}{l}49^{\circ} 12^{\prime} 15^{\prime \prime N} \\
19^{\circ} 13^{\prime} 38^{\prime \prime E}\end{array}$ & $\begin{array}{l}49^{\circ} 12^{\prime} 32^{\prime \prime} \mathrm{N} \\
19^{\circ} 14^{\prime} 30^{\prime \prime} \mathrm{E}\end{array}$ & $\begin{array}{l}49^{\circ} 13^{\prime} 38^{\prime \prime} \mathrm{N} \\
19^{\circ} 15^{\prime} 46^{\prime \prime} \mathrm{E}\end{array}$ & $\begin{array}{l}49^{\circ} 14^{\prime} 29^{\prime \prime} \mathrm{N} \\
19^{\circ} 17^{\prime} 20^{\prime \prime} \mathrm{E}\end{array}$ \\
\hline Distance from ES & $0 \mathrm{~m}$ & $830 m$ & $1,898 m$ & $4,404 \mathrm{~m}$ & $6,876 \mathrm{~m}$ \\
\hline Altitude (a.s.l.) & $458 \mathrm{~m}$ & $491 \mathrm{~m}$ & $480 \mathrm{~m}$ & $553 \mathrm{~m}$ & $546 \mathrm{~m}$ \\
\hline Soil type & - & cambisols & cambisols & leptosols & cambisols \\
\hline Soil texture & - & sandy loam & clay loam & loam & clay loam \\
\hline Stoniness & - & slightly stony & very stony & very stony & very stony \\
\hline $\mathrm{pH}$ & - & $6.3 \pm 0.15$ & $5.7 \pm 0.46$ & $6.3 \pm 0.10$ & $6.9 \pm 0.37$ \\
\hline $\mathrm{C}_{\mathrm{ox}}(\%)$ & - & $1.78 \pm 0.15$ & $1.55 \pm 0.05$ & $2.11 \pm 0.10$ & $3.57 \pm 0.12$ \\
\hline $\mathrm{N}\left(\mathrm{NO}_{3}\right)\left(\mathrm{mg} \cdot \mathrm{kg}^{-1}\right)$ & - & $4.58 \pm 1.30$ & $5.90 \pm 2.24$ & $7.35 \pm 1.25$ & $4.68 \pm 1.39$ \\
\hline $\mathrm{N}\left(\mathrm{NH}_{4}\right)\left(\mathrm{mg} \cdot \mathrm{kg}^{-1}\right)$ & - & $8.40 \pm 2.97$ & $6.03 \pm 0.93$ & $13.20 \pm 1.18$ & $6.43 \pm 0.81$ \\
\hline Soil moisture (\%) & - & $21.50 \pm 0.92$ & $21.05 \pm 1.71$ & $22.38 \pm 1.26$ & $31.42 \pm 1.00$ \\
\hline
\end{tabular}

Soil sampling and analysis (geo-chemical properties; trace elements)

Four sites $(1-4)$ were sampled in a downwind direction from the emission source along $7-\mathrm{km}$ transect (Fig. 1). Samples were taken in May 2009 from the surface horizon $(0-20 \mathrm{~cm})$ of permanent grasslands by a quadrant sampling method. For each site, four replicates, consisting from four mixed up subsamples, were taken. An analysis for each replicate was performed separately and the average was calculated. The detailed description of individual sampling sites is in the Table 1.

Soil samples were processed as followed:

1) Soil moisture was measured gravimetrically by drying the replicates to a constant weight at $105^{\circ} \mathrm{C}$.

2) $\mathrm{C}_{\mathrm{ox}}$ was determined by a titration with the $\mathrm{K}_{2} \mathrm{Cr}_{2} \mathrm{O}_{7} / \mathrm{H}_{2} \mathrm{SO}_{4}$. scored: (1) the total abundance; (2) genera richness, expressed by an average number of genera per site and (3) following ecological indices: Enrichment Index (EI), Structure Index (SI) and Channel Index (Cl) by Ferris et al. (2001). Nematodes were assigned to trophic and c-p groups according to Nemaplex (http://plpnemweb. ucdavis.edu/nemaplex/) and Yeates et al. (1993). Due to the different proportion of genera in the samples, nematodes were divided into eudominant $(>10 \%)$, dominant $(5-10 \%)$ and subdominant $(<5 \%)$ groups (Losos et al., 1984).

\section{Data analysis}

For the analysis of the ecological distance among sites (nematode community and soil parameters), a constrained ordination redundancy analysis (RDA) was used and data were processed 
Table 2. Total $\left(\mathrm{HNO}_{3}\right)$ and mobilizable content $\left(\mathrm{Na}_{2} \mathrm{EDTA}\right)$ of trace elements; average values \pm S.D

\begin{tabular}{|c|c|c|c|c|}
\hline \multirow{2}{*}{ Trace Element } & \multicolumn{4}{|c|}{ Site } \\
\hline & 1 & 2 & 3 & 4 \\
\hline \multicolumn{5}{|c|}{ Total element content - $\mathrm{HNO}_{3}$ extraction } \\
\hline Chromium & $12.802 \pm 2.732$ & $3.028 \pm 0.372$ & $1.080 \pm 0.060$ & $2.422 \pm 2.389$ \\
\hline Copper & $3.466 \pm 0.197$ & $2.462 \pm 1.530$ & $7.334 \pm 1.504$ & $7.505 \pm 0.523$ \\
\hline Nickel & $1.830 \pm 0.147$ & $1.705 \pm 0.170$ & $2.994 \pm 0.398$ & $3.367 \pm 0.288$ \\
\hline Lead & $1.886 \pm 0.105$ & $1.658 \pm 0.091$ & $2.502 \pm 0.219$ & $2.315 \pm 0.236$ \\
\hline \multicolumn{5}{|c|}{ Element mobilizable fraction - $\mathrm{Na}_{2} \mathrm{EDTA}$ extraction } \\
\hline Chromium & $0.606 \pm 0.254$ & $0.480 \pm 0.089$ & $0.764 \pm 0.208$ & $0.879 \pm 0.165$ \\
\hline Copper & $17.290 \pm 2.414$ & $19.908 \pm 1.451$ & $15.060 \pm 0.258$ & $14.043 \pm 1.709$ \\
\hline Nickel & $6.002 \pm 0.620$ & $4.657 \pm 0.782$ & $2.174 \pm 0.293$ & $1.868 \pm 0.388$ \\
\hline Lead & $3.033 \pm 0.278$ & $3.048 \pm 0.226$ & $1.687 \pm 0.148$ & $1.631 \pm 0.277$ \\
\hline
\end{tabular}

by CANOCO 5 software (Ter Braak \& Šmilauer, 2012). The significance of the axis was tested by Monte Carlo permutation test. Differences in nematode community mean traits and indices among individual sites (Table 4) were tested by Duncan Test at the level $P<0.05$.

\section{Results}

\section{Heavy metals}

The concentrations of trace elements $\left(\mathrm{HNO}_{3}\right.$ and $\mathrm{Na}_{2}$ EDTA extraction) are summarized in Table 2. Chromium was identified as the most considerable pollutant what highly exceeded the contamination limit of $10 \mathrm{mg} \mathrm{kg}^{-1}$ (MARD, 1994) at site 1, while the contents of remaining trace elements $(\mathrm{Cu}, \mathrm{Ni}, \mathrm{Pb})$ were relatively low. Despite the decreasing trend of the total $\mathrm{Cr}$ content along the transect, mobilizable fraction of $\mathrm{Cr}$ increased with the distance similarly as $\mathrm{C}_{\mathrm{ox}}$ (Fig. 2), soil pH and moisture as an important factors for the availability of this element (Fig. 2).
Nematode community structure

Overall, 49 nematode genera were identified (Table 3 ) comprised bacterivores (17), fungivores (4), omnivores (6), predators (7) and plant-feeders (15). By the frequency of nematode occurrence, the genus Rhabditis was always found to be eudominant and genera Aphelenchus, Aporcelaimellus, Axonchium, Boleodorus, Cephalobus, Dorylaimellus, Dorylaimus, Helicotylenchus, Pratylenchus, Rotylenchus and Tylencholaimus were largely classified as dominant (Table 3). The RDA analysis of the nematode communities divided the genera into the two main groups (Fig. 3). The first one was clustered towards site 4, with the best conditions for Axonchium, Dorylaimellus, Eudorylaimus and Tylencholaimus. The second cluster was uniformly distributed between site 1 and 2 , with Aporcelaimellus and Pratylenchus prospering under these conditions. This generic distribution resembles the distribution of mobilizable fractions of $\mathrm{Cr}$ and on the other side, $\mathrm{Cu}, \mathrm{Ni}$ and $\mathrm{Pb}$ (Figs. 2 and 3). With respect to c-p groups, significant preference of c-p 3 nematodes was found towards to the concentration of $\mathrm{Cu}, \mathrm{Ni}$ and $\mathrm{Pb}$ (Fig. 2). Along tran-

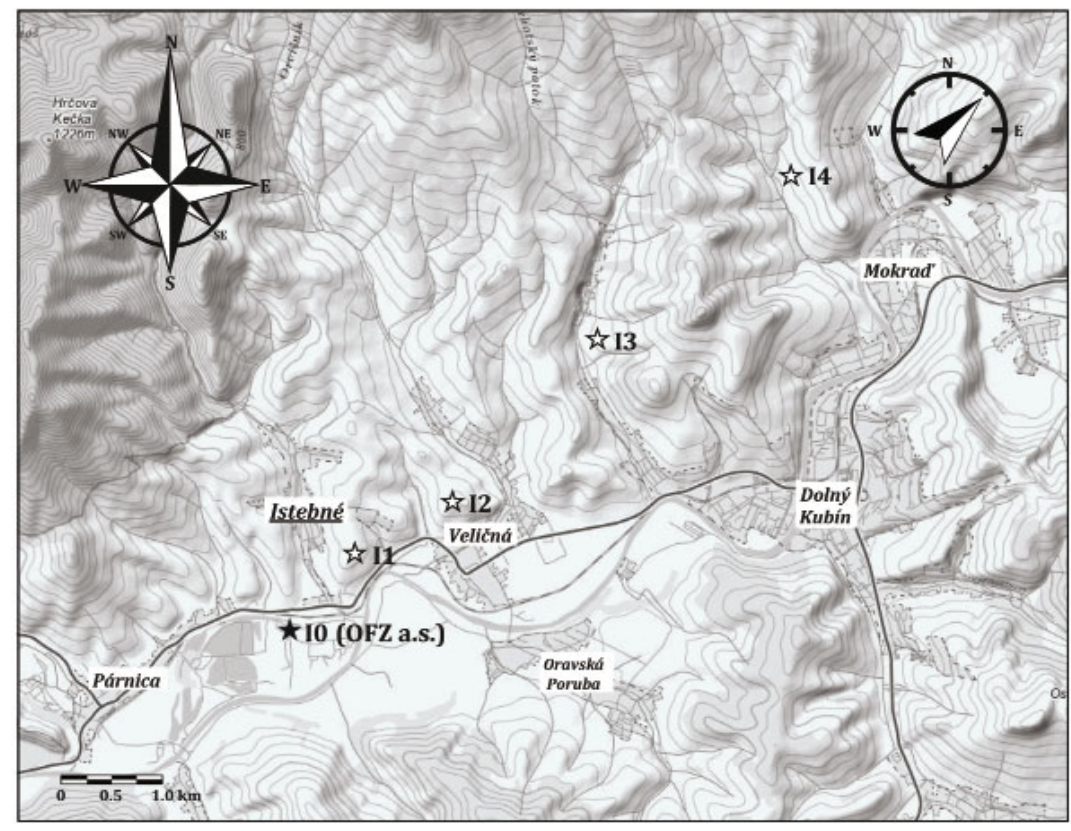

Fig. 1. Map of the study area with the indication of the emission source 10 ( 


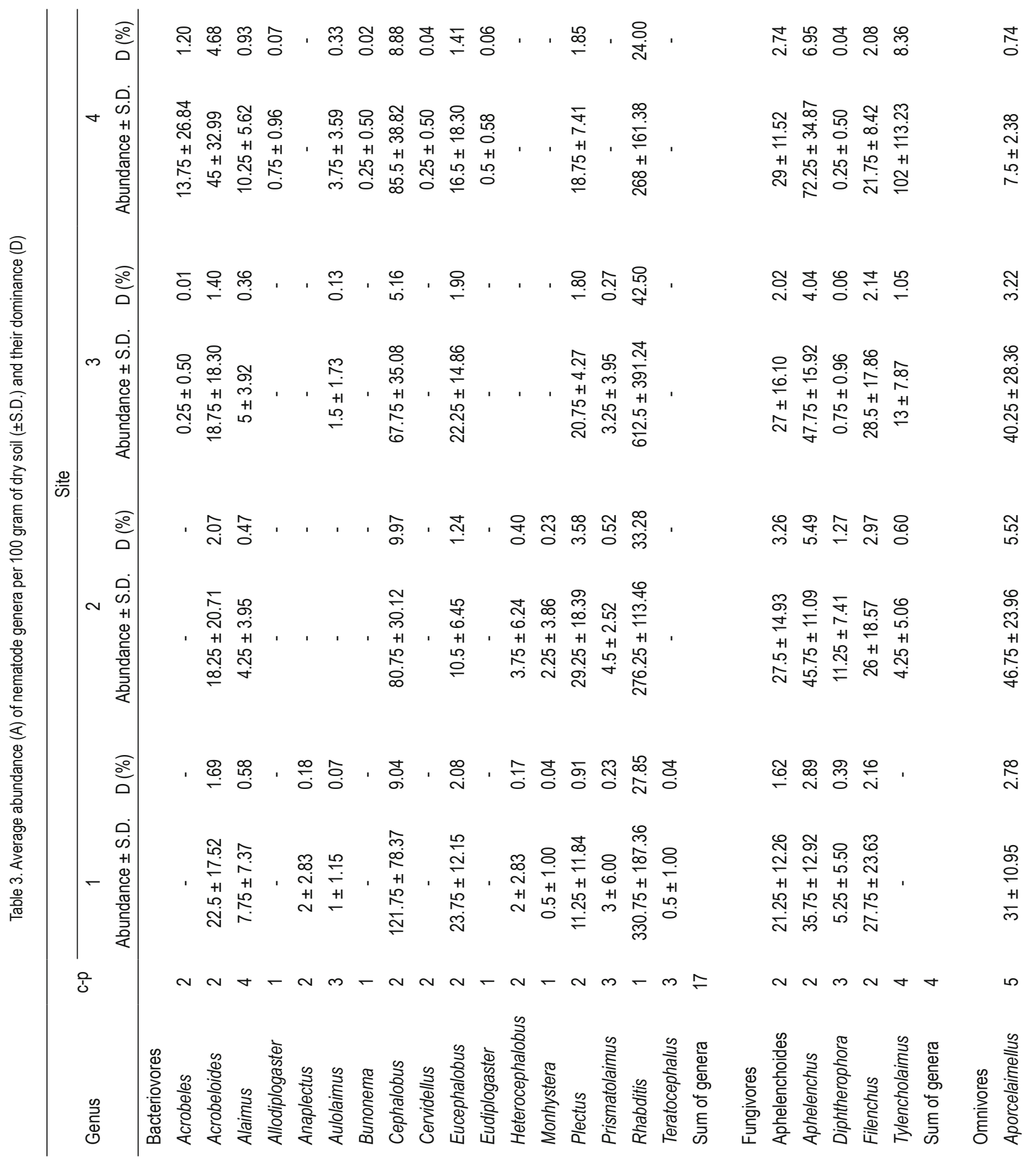




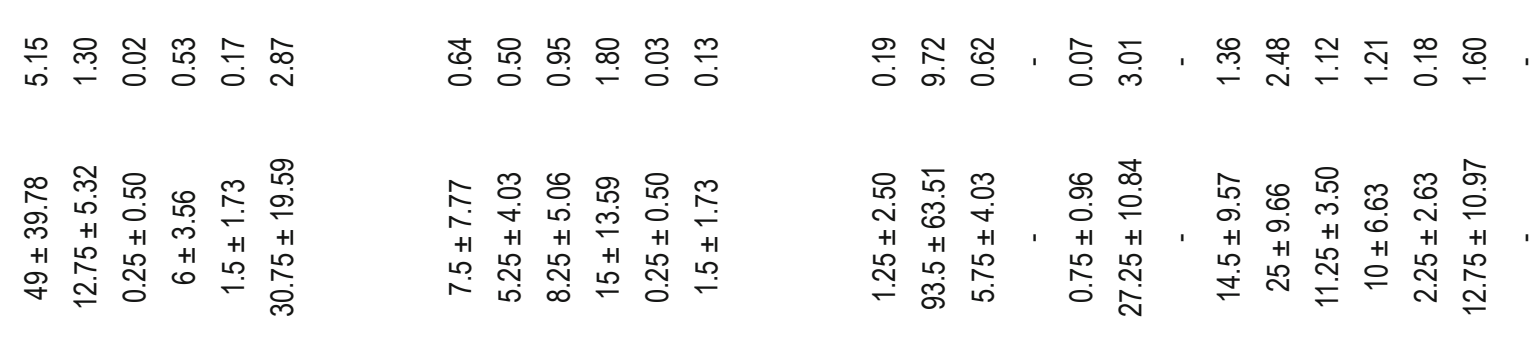

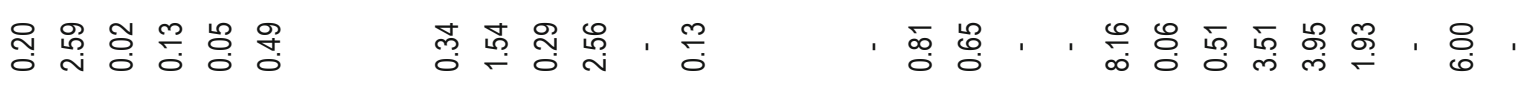

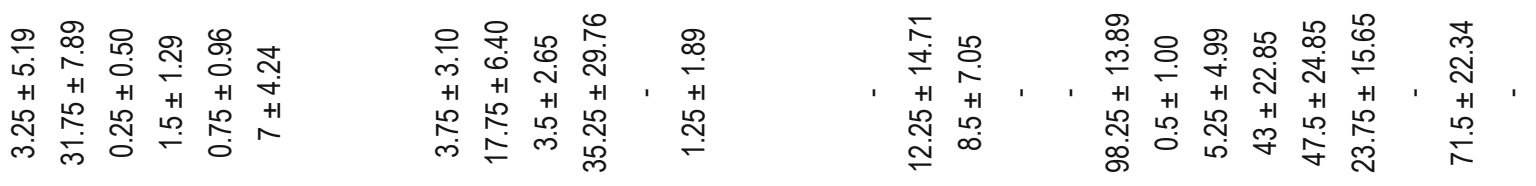

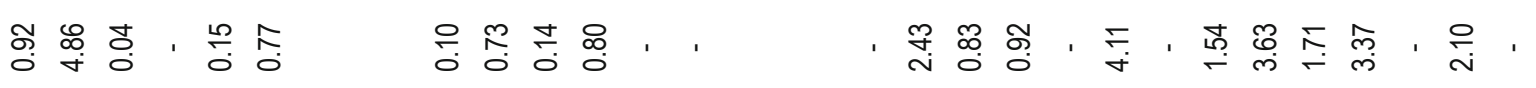

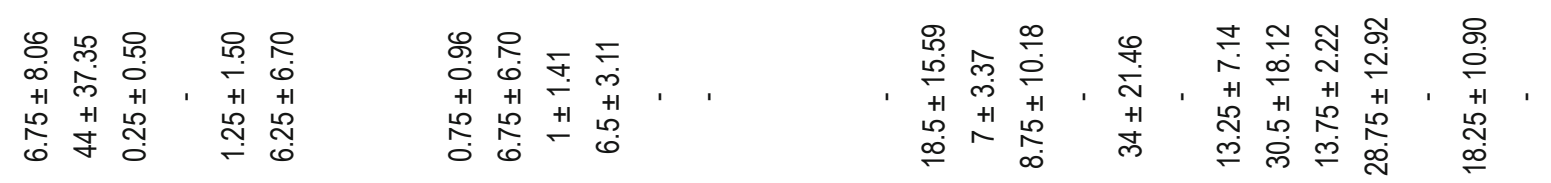

务

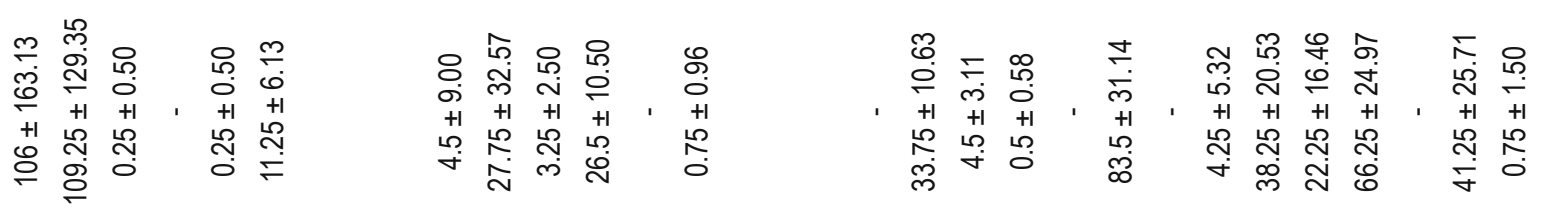

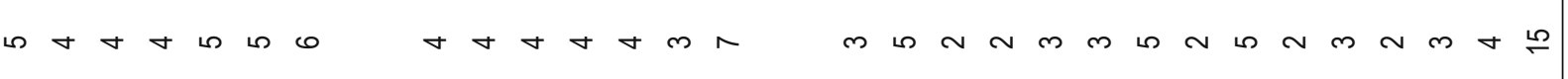

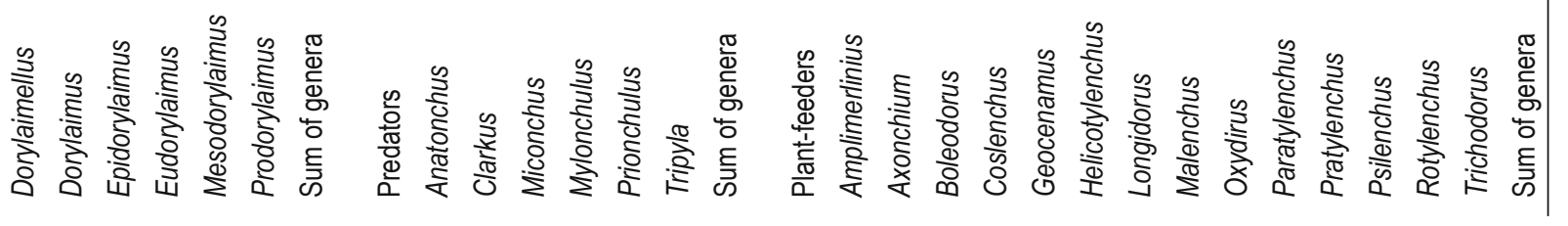




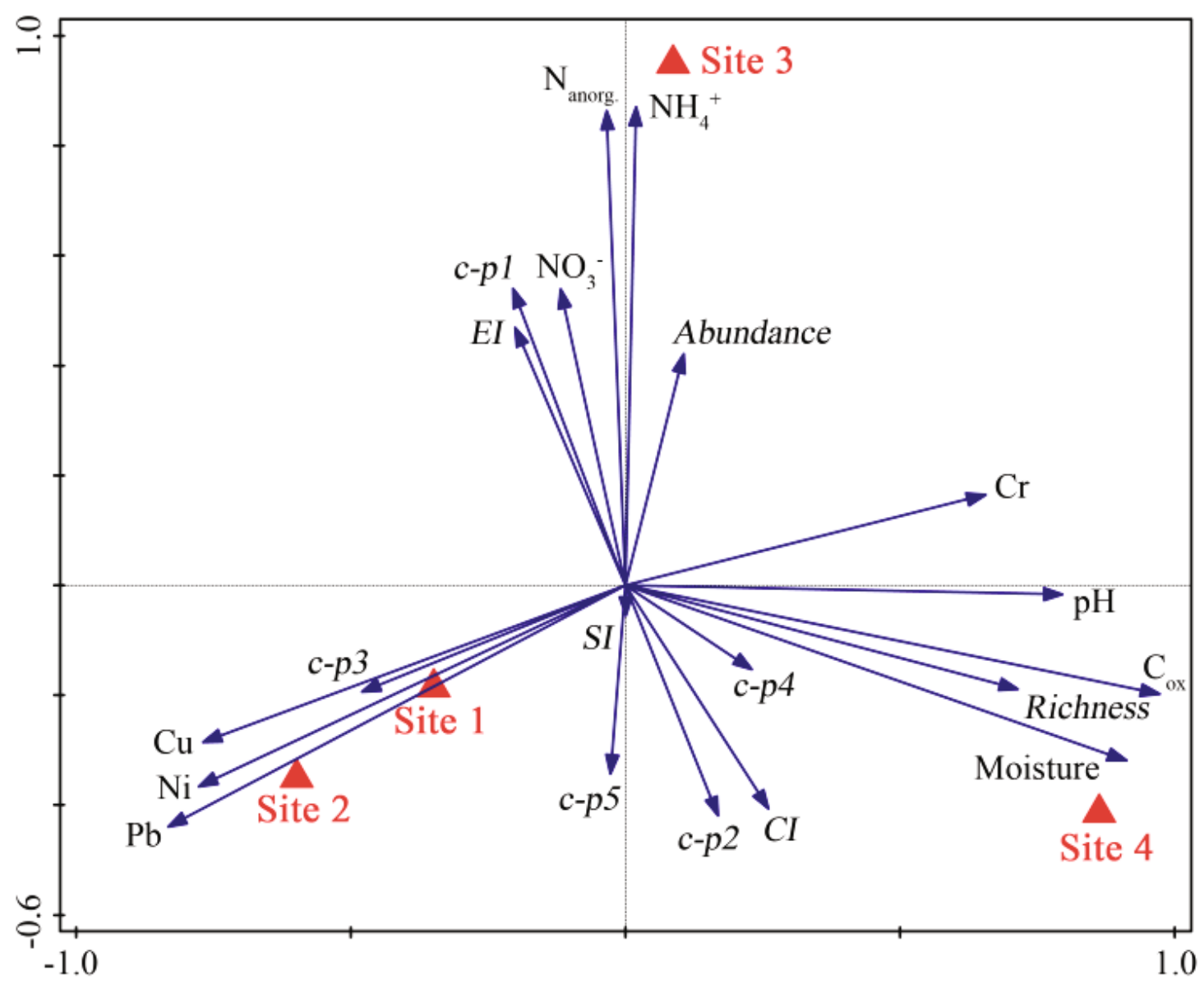

Fig. 2. Redundancy analysis (RDA) performed on physicochemical soil properties, trace elements and selected indices in relation to sampling sites. Explanatory variables account for $52.8 \%$ of the variation for all axes; $\mathrm{F}=4.5 ; \mathrm{P}=0.002$. Richness is genera richness, Moisture is soil moisture.

sect, opportunistic nematodes from c-p groups 1 and 2 were always dominant, but higher c-p groups also occur rather frequently at all sites (Table 4). This relatively complex and stable structure of nematode populations indicates ecosystem lacking obvious stress signs. The increasing trend of the mobilizable $\mathrm{Cr}$ was in positive correla- tion with the nematode diversity (Fig. 2), what documented significantly higher rates of generic richness at site 4 (Table 4). Other elements, on the other hand, showed an opposing effect (Fig. 2). Similar, effect was recognised also for the nematode abundance, mostly found to be over 1000 individuals per $100 \mathrm{~g}$ of soil (Table 4).

Table 4. Average values for ecological indices and proportion of trophic and c-p groups in structure of nematode communities $( \pm S$.D.)

\begin{tabular}{|c|c|c|c|c|}
\hline \multirow{2}{*}{ Indices and c-p groups } & \multicolumn{4}{|c|}{ Site } \\
\hline & 1 & 2 & 3 & 4 \\
\hline Genera Richness & $27.75 \pm 2.87^{\mathrm{a}}$ & $27.75 \pm 0.5^{\mathrm{a}}$ & $29.25 \pm 2.22^{\mathrm{a}}$ & $33 \pm 2.31^{c}$ \\
\hline Abundance & $1232.75 \pm 269.91^{\mathrm{a}}$ & $837.5 \pm 145.39^{a}$ & $1325.75 \pm 445.84^{a}$ & $1038.25 \pm 311.38^{a}$ \\
\hline Enrichment Index & $82.21 \pm 10.04^{a}$ & $81.95 \pm 9.27^{a}$ & $89.65 \pm 5.51^{\mathrm{a}}$ & $76.55 \pm 10.57^{a}$ \\
\hline Structural Index & $84.83 \pm 8.18^{\mathrm{a}}$ & $72.6 \pm 10.58^{a}$ & $75.69 \pm 12^{a}$ & $77.28 \pm 12.54^{a}$ \\
\hline Channel Index & $7.56 \pm 5.63^{\mathrm{a}}$ & $9.38 \pm 5.64^{a}$ & $5.29 \pm 3.4^{a}$ & $12.71 \pm 6.69^{a}$ \\
\hline$c-p 1$ & $36.92 \pm 20.04^{\mathrm{ab}}$ & $41.73 \pm 13.71^{\mathrm{ab}}$ & $56.07 \pm 14.08^{b}$ & $29.76 \pm 11.29^{a}$ \\
\hline c-p2 & $27.24 \pm 7.18^{\mathrm{a}}$ & $36.54 \pm 9.99^{a}$ & $25.4 \pm 10.7^{a}$ & $38.35 \pm 11.52^{\mathrm{a}}$ \\
\hline c-p3 & $1.09 \pm 1.3^{\mathrm{ab}}$ & $2.27 \pm 1.07^{b}$ & $0.86 \pm 0.91^{\mathrm{ab}}$ & $0.64 \pm 0.26^{a}$ \\
\hline c-p4 & $19.13 \pm 16.94^{\mathrm{a}}$ & $9.9 \pm 4.16^{\mathrm{a}}$ & $12.22 \pm 4.61^{\mathrm{a}}$ & $19.37 \pm 11.19^{a}$ \\
\hline c-p5 & $15.62 \pm 14.13^{a}$ & $9.56 \pm 4.41^{\mathrm{a}}$ & $5.46 \pm 2.87^{\mathrm{a}}$ & $11.87 \pm 5.42^{\mathrm{a}}$ \\
\hline
\end{tabular}




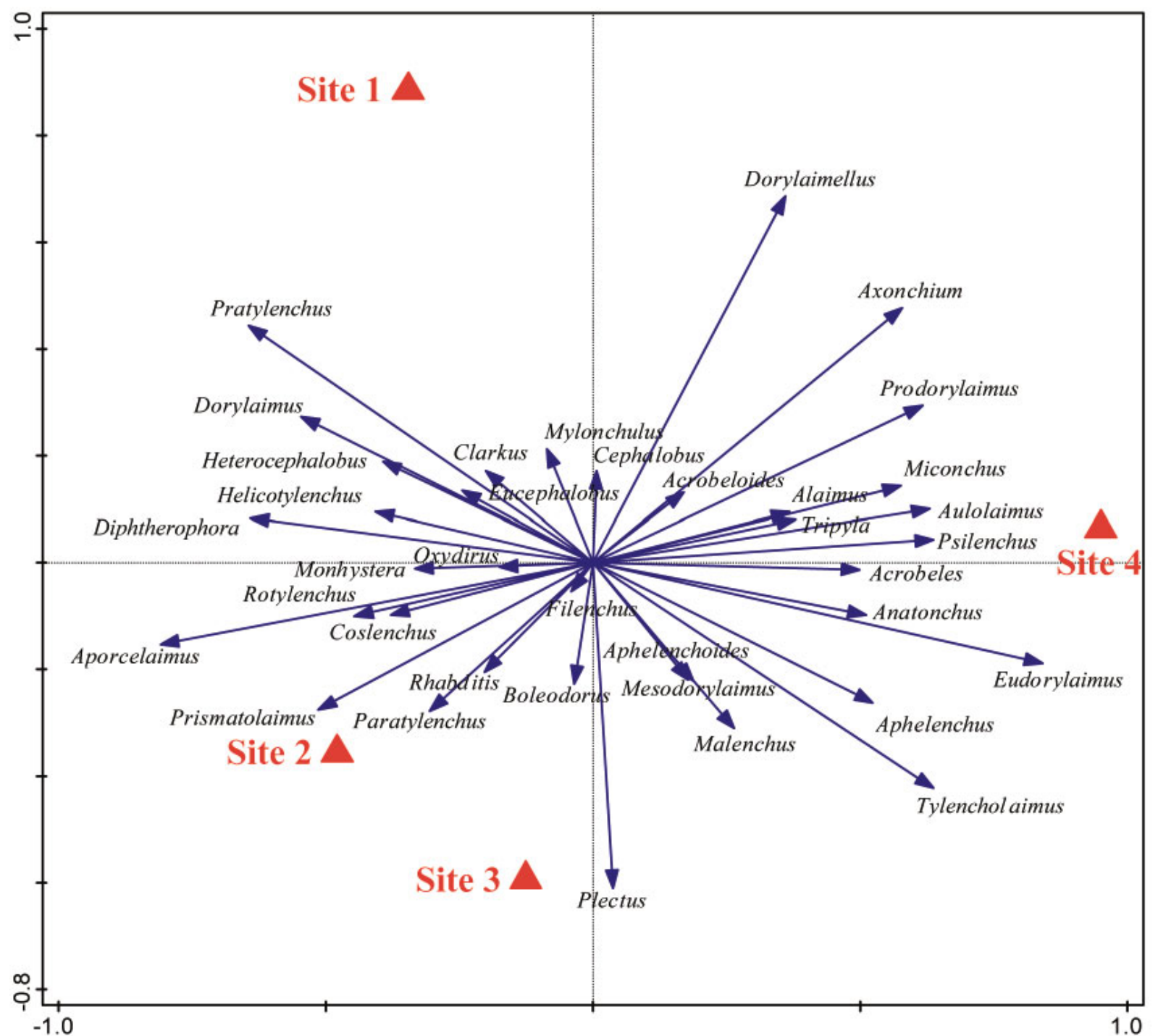

Fig. 3. Redundancy analysis (RDA) performed on the generic composition in relation to sampling sites with data explained $41.9 \%$ of the variation in the first two axes;

\section{Ecological Indices}

SI and El confirmed the low level of disturbance in ecosystem and maturing food web (Fig. 4). This was confirmed also by low correlation of SI with the trace elements (Fig. 2). With respect to the maturing communities, the decomposition rate decreased as indicated $\mathrm{Cl}$, what could mean increasing participation of fungi in the processes of organic matter breakdown (Fig. 2).

\section{Discussion}

The present study provides an assessment of the long-term effect of industrial emissions release on soil nematode communities. We hypothesized, that more than 50 years of continuous aerial deposition emitted from OFZ a. s. could have increased the contents of several heavy metals with severe ecotoxicological impacts as showed in some earlier studies (Haimi \& Mätäsniemi, 2002; Pen-Mouratov et al., 2010; Šalamún et al., 2012). The Cr contamination detected in our research is relatively high, though mobility of this element was found low, probably due to specific soil properties and high bounding of $\mathrm{Cr}$ by the soil components e.g. organic matter content (Vrana et al., 1997), which transform and immobilize highly toxic $\mathrm{Cr}$ ions. Any transition between $\mathrm{Cr}^{3+}$ and $\mathrm{Cr}^{6+}$ in the soils has great environmental and health implications because of nutritional importance and a strong toxicity for plants and animals, respectively (Kabata-Pendias, 2011).

Except direct toxicity the elevation of $\mathrm{Cr}$ content might affect the important soil processes e.g. decomposition or nitrification (Rüdel et al., 2001) and alter the soil biota composition (microorganisms, earthworms, enchytraeids and springtails) by retardation or losing the key communities (Molnár et al., 1989; Lock \& Jansen, 2002; Huang et al., 2009). However, the doses used in these experimental studies were significantly higher in comparison with our data obtained from natural conditions. This is probably reason for the low modification and well-structured composition of nematode communities in close vicinity of the factory.

Nagy et al. (2004) established the threshold dose at rate 0.5 mg. kg-1 for mobilizable $\mathrm{Cr}$, where the affects for nematodes start to be observable. In our study, this concentration was exceeded at 


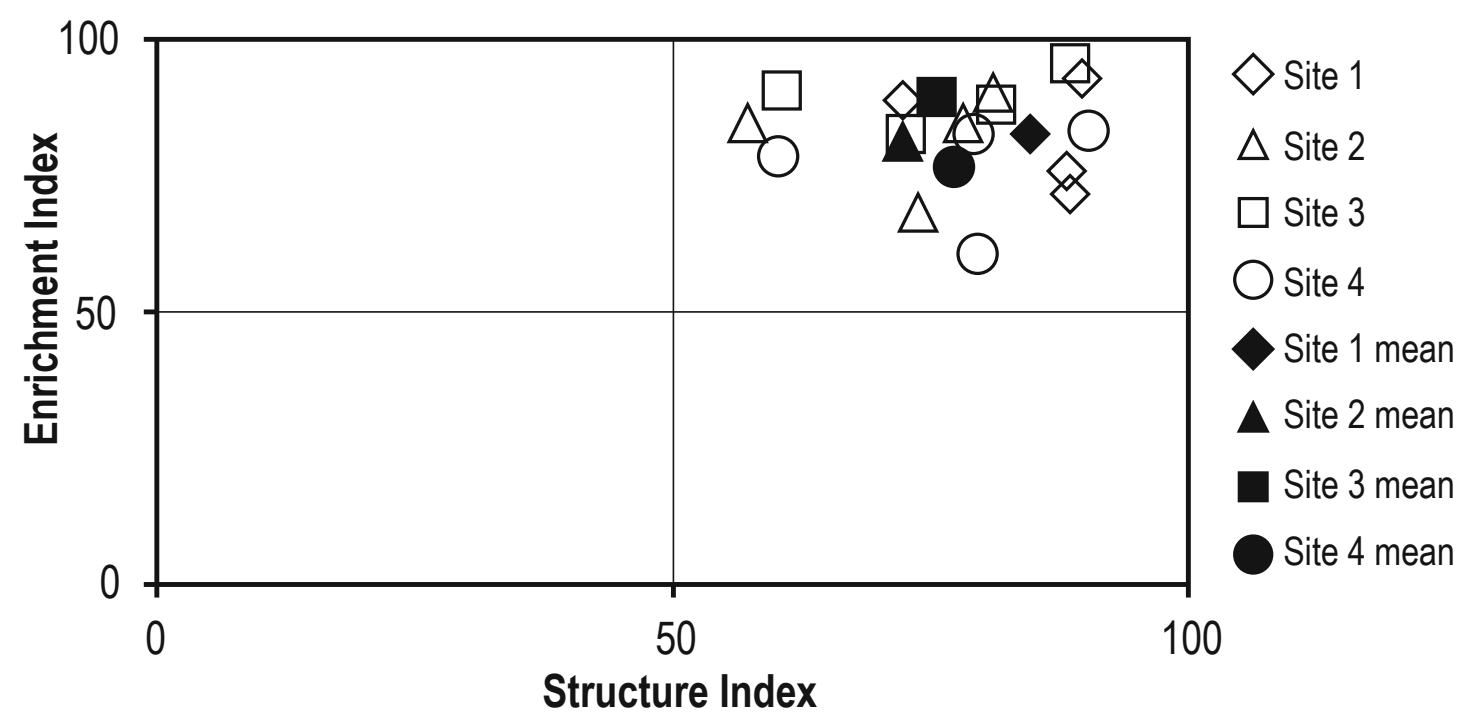

Fig. 4. Structural and Enrichment Indices for the observed sites

all sites except site 2, what was reflected by maximum abundance of the c-p 3 and 5 group at this site. On the contrary, the highest proportions of c-p 4 group (with similar sensitivity to environmental disturbances) in communities were found at sites 1 and 4 with highest contents of trace elements. For example, representatives of fungivorous Tylencholaimus from c- $p 4$ group were as abundant as bacterivores Rhabditis (c-p 1) or Cephalobus (c-p 2) at site 4. High abundance of Tylencholaimus could be associated with detected large $C_{\text {ox }}$ values, usually accompanying by plentiful communities of decomposers. Possible resistance of Tylencholaimus nematodes to $\mathrm{Cr}$ contamination might also play role in their survival, but there are some studies that rebut this idea (Nagy et al., 2004; Ekschmitt \& Korthals, 2006; Pen-Mouratov et al., 2010). Consequently, we presume that under low contamination levels, additional factors could play role in the formation of the nematode community. For example, the grassland is more complex ecosystem in the foodweb connections and has higher resilience and buffering capacity than an agricultural field in experiment conducted by Nagy et al. (2004). This brings us to the conclusion that manifestation of a stress factor of the same intensity can vary in dependence on the ecosystem type and particular environmental conditions.

As the generic richness showed, increasing content of mobilizable $\mathrm{Cr}$ towards site 4 had positive effect on nematode diversity with increase of highly sensitive genera such as Alaimus, Anatochus, Eudorylaimus, Mesodorylaimus, Miconchus, Prodorylaimus and Tylencholaimus. Similar diversity stimulation under conditions with the low contamination level published Yeates et al. (1994) and Nagy et al. (2004). On the other hand, Park et al. (2011) found serious negative changes in the nematode community structure in soils contaminated by low levels of mobilizable $\mathrm{Cr}$. Nevertheless, the strong toxic effect on nematodes was probably outcome of joint toxicity with other heavy metals and thus is hard to quantify and compare the direct impact of $\mathrm{Cr}$ itself presented in this study. The ecological index SI has proved to be a good tool for the ecosystem assessment and evaluation of natural or artificial stressors in the soil (Park et al., 2011). As SI development along the tran- sect showed, no significant stress tendencies in the soil ecosystem were present at the investigated sites. Relatively high $\mathrm{El}$ and low $\mathrm{Cl}$ at all sites indicated enriched environmental conditions with dominancy of bacteria as primary detrital consumers. The shift towards higher importance of fungi in ecosystem and breakdown of more complex organic matter was found mainly at site 4. According to these findings, the impact of industrial emissions was not as severe as in experiments described by Nagy et al. (2004) where similar content of mobilizable $\mathrm{Cr}$ caused significant depression of the nematode diversity profile and a subversion of nematode communities even after several years.

\section{Conclusion}

The long-term aerial deposition of the emissions in close surrounding of Oravské Ferozliatinárske Závody a.s. in Slovakia has had not severe and harmful effect on soil nematode communities as it was predicted. Relatively moderate influence of mobilizable $\mathrm{Cr}$ and other heavy metals on nematode community could be explained by more complex interaction of several factors, including the overall low level of contamination and geochemical properties of ecosystem. In addition, the intensity and exposure time of contaminant inputs could be important, because slower soil contamination process running over relatively long period gives the native communities enough time for adaptation.

\section{Acknowledgments}

The authors acknowledge the support of the Slovak Research Development Agency (project LPP-0085-09) (0.4), VEGA (Projects No. 2/0193/14) (0.3) and project "Application Centre to protect humans, animals and plants against parasites" (Code ITMS: 26220220018) based on the support of the Operational Program "Research and Development" funded from the European Regional Development Found (0.3). 


\section{References}

Bongers, T., Ferris, H. (1999): Nematode community structure as a bioindicator in environmental monitoring. Trends Ecol. Evol., 14(6): 224 - 228. DOI: 10.1016/S0169-5347(98)01583-3

EkschmitT, K., KoRthals, G.W. (2006): Nematodes as sentinels of heavy metals and organic toxicants in the soil. J. Nematol., 38(1): $13-19$

FARGAŠovÁ, A. (2009): Metal contamination in Slovakia. Retrieved May 15, 2014 from http://www.enviro-edu.sk/?page=environmentalne_problemy/znecistenie_kovmi_na_slovensku. (In Slovak)

Ferris, H., Bongers, T., De Goede, R. G. M. (2001): A framework for soil food web diagnostics: extension of the nematode faunal analysis concept. Appl. Soil Ecol., 18(1): 13 - 29. DOI: 10.1016/ S0929-1393(01)00152-4

HAIMI, J., MÄTÄSNIEMI, L. (2002): Soil decomposer animal community in heavy-metal contaminated coniferous forest with and without liming. Eur. J. Soil Biol., 38(2): 131 - 136. DOI: 10.1016/S11645563(02)01134-2

Huang, S., Peng, B., Yang, Z., Chal, L., Zhou, L. (2009): Chromium accumulation, microorganism population and enzyme activities in soils around chromium-containing slag heap of steel alloy factory. Trans. Nonferrous Met. Soc. China., 19(1): 241 - 248. DOI: 10.1016/S1003-6326(08)60259-9

Kabata-Pendias, A. (2011): Trace Elements in Soils and Plants (4th edition). CRC Press, Taylor and Francis Group, Boca Raton, USA. Kropitz, P., PIvarčı, M. (1998): Land Use Plan - Žilinský district [ÚPN-VÚC Žilinského kraja] (In Slovak)

LI, Q., JIANG, Y., LIANG, W.J. (2006): The effect of heavy metals on soil nematode communities in the vicinity of a metallurgical factory. J. Environ. Sci. (China), 18(2): 323 - 328. DOI: 10.3321/j. issn:1001-0742.2006.02.021

LOCK, K., JANSSEN, C.R. (2002): Ecotoxicity of chromium (III) to Eisenia fetida, Enchytraeus albidus, and Folsomia candida. Ecotoxicol. Environ. Saf., 51(3): 203 - 205. DOI: 10.1006/eesa.2001.2122 Losos, B. GuličKa, J., Lellák, J., PeliKÁn, J. (1984): Ekologie Živočíchů. Praha: Státní pedagogické nakladatelství. pp. 1-320. MARD (1994): Ministry of Agriculture and Rural Development Degree No. 531/1994-540. Retrieved from http://www.mpsr.sk. (In Slovak)

MARD (2005): Ministry of Agriculture and Rural Development Degree No. 338/2005. Retrieved from http://www.mpsr.sk (In Slovak) MolnÁr, L., Fisher, E., KÁlLAY, M. (1989): Laboratory studies of the effect, uptake and distribution of chromium in Eisenia loetida (Anelida, Oligochaeta). Zool. Anz., 223: 57 - 66

Nagy, P. Bakónyi, G., Bongers, T., Kádár, I., Fáblán, M., Kiss, I. (2004): Effects of microelements on soil nematode assemblages seven years after contaminating an agricultural field. Sci. Total Environ., 320: 131 - 143 DOI: 10.1016/j.scitotenv.2003.08.006

Neher, D.A., Weicht, T.R., Moorhead, D.L., Sinsabaugh, R.L. (2004). Elevated $\mathrm{CO}_{2}$ alters functional attributes of nematode communities in forest soils. Funct. Ecol., 18(4): 584 - 591. DOI: 10.1111/j.02698463.2004.00866.x
NemapLeX - Retrieved from http://plpnemweb.ucdavis.edu/nemaplex/

PARK, B., LeE, J., Ro, H., KIm, Y.H. (2011): Effects of heavy metal contamination from an abandoned mine on nematode community structure as an indicator of soil ecosystem health. Appl. Soil Ecol., 51: 17 - 24. DOI: 10.1016/j.apsoil.2011.08.006

Pen-Mouratov, S., Shukurov, N., Steinberger, Y. (2010): Soil free-living nematodes as indicators of both industrial pollution and livestock activity in Central Asia. Ecol. Indic., 10(5): 955 - 967. DOI: 10.1016/j.ecolind.2010.02.005

Rüdel, H., Wenzel, A., Terytze, K. (2001): Quantification of soluble chromium (VI) in soils and evaluation of toxicological effects. Environ. Geochem. Health, 23: 219 - 224. DOI: 10.1023/A:1012253504440

SabienË, N., BrazauskienË, D. M., Rimmer, D. (2004): Determination of heavy metal mobile forms by different extraction methods. Ekologija, 1: $36-41$

Šalamún, P., Renčo, M., Miklisová, D., Hanzelová, V. (2011): Nematode community structure in the vicinity of a metallurgical factory. Environ. Monit. Assess., 183(1 - 4): 451 - 464. DOI: 10.1007/ s10661-011-1932-y

Šalamún, P., Renčo, M., Kucanová, E., Brázová, T., Papajová, I., Miklisová, D., Hanzelová, V. (2012): Nematodes as bioindicators of soil degradation due to heavy metals. Ecotoxicology, 21(8): 2319 - 30. DOI: 10.1007/s10646-012-0988-y

SÁnchez-Moreno, S., NavAs, A. (2007): Nematode diversity and food web condition in heavy metal pollutes soils in river basin in southern Spain. Eur. J. Soil Biol., 43(3): 166 - 179. DOI: 10.1016/j. ejsobi.2007.01.002

SOUTHEY, J. F. (1986): Laboratory methods for work with plant and soil nematodes. Norwich: H.M.S.O. Books. pp. $1-202$.

Ter BraAk, C.J.F., Šmilauer, P. (2012): Canoco reference manual and user's guide: software for ordination, version 5.0. Microcomputer Power. Ithaca, USA, 496 pp.

Van Bezooljen, J. (2006): Methods and techniques for nematology. 112 p. Retrieved from http://www.nem.wur.nl/NR/rdonlyres/ CC0A519F-3ADD-4FFA-B473-959062BC9C7F/47007/ MethodsandTechniquesforNematology1.pdf

Vrana, K., Rapant, S., Bodiš, D., Marsina, K., MañKovská, B., Čurlík, J., ŠefČík, P., Daniel J., LuČIVJanskÝ, L., LeXA, J., Pramuka, S. (1997): Geochemical atlas of the Slovak Republic at a scale of 1 : 1,000,000. J. Geochem. Explor., 60(1): 7 - 37. DOI: 10.1016/ S0375-6742(97)00023-X

Yeates, G.W., Bongers, T., De Goede, R.G.M., Freckman, D.W., GEORGIEVA, S.S. (1993). Feeding habits in soil nematode families and genera - an outline for soil ecologists. J. Nematol., 25: 315 - 331

Yeates, G.W., Orchard, V.A., Speir, T.W., Hunt, J.L., Hermans, M.C.C. (1994): Impact of pasture contamination by copper, chromium, arsenic timber preservative on soil biological activity. Biol. Fertil. Soils, 18: 200 - 208. DOI: 10.1007/BF00647667

Zhang, W.D., Wang, X.F., LI, Q., JiAnG, Y., LIANG, W.J. (2007). Soil nematode responses to heavy metal stress. Helminthologia, 44(2): 87 - 91. DOI: 10.2478/s11687-007-0009-5 